\title{
Trends in Mediterranean gridded temperature extremes and large-scale circulation influences
}

\author{
D. Efthymiadis ${ }^{1,2}$, C. M. Goodess ${ }^{1}$, and P. D. Jones ${ }^{1}$ \\ ${ }^{1}$ Climatic Research Unit, School of Environmental Sciences, University of East Anglia, Norwich, UK \\ ${ }^{2}$ Centre for Climate Change, Geography Department, University Rovira i Virgili, Tortosa, Spain
}

Received: 7 October 2010 - Revised: 28 March 2011 - Accepted: 10 June 2011 - Published: 12 August 2011

\begin{abstract}
Two recently-available daily gridded datasets are used to investigate trends in Mediterranean temperature extremes since the mid-20th century. The underlying trends are found to be generally consistent with global trends of temperature and their extremes: cold extremes decrease and warm/hot extremes increase. This consistency is better manifested in the western part of the Mediterranean where changes are most pronounced since the mid-1970s. In the eastern part, a cooling is observed, with a near reversal in the last two decades. This inter-basin discrepancy is clearer in winter, while in summer changes are more uniform and the west-east difference is restricted to the rate of increase of warm/hot extremes, which is higher in central and eastern parts of the Mediterranean over recent decades. Linear regression and correlation analysis reveals some influence of major large-scale atmospheric circulation patterns on the occurrence of these extremes - both in terms of trend and interannual variability. These relationships are not, however, able to account for the most striking features of the observations - in particular the intensification of the increasing trend in warm/hot extremes, which is most evident over the last $15-20 \mathrm{yr}$ in the Central and Eastern Mediterranean.
\end{abstract}

\section{Introduction}

Mediterranean temperature extremes are a major concern with respect to their potential impacts on natural and human systems. The extreme high temperatures experienced in Athens during the summer of 2007 (Tolika et al., 2009), for example, were associated with wide-spread peri-urban wildfires as well as deaths and other human health impacts. Earlier global and European studies indicate that extreme tem-

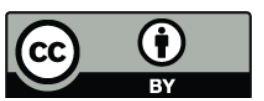

Correspondence to: C. M. Goodess (c.goodess@uea.ac.uk) perature events of daily/multi-daily scales in the Mediterranean have undergone changes in the course of the 20th century whose overall long-term trends are in accordance with the global picture of trends: cold extremes are reduced and warm/hot extremes are increased (Frich et al., 2002; Yan et al., 2002; Klein Tank and Können, 2003; Moberg and Jones, 2005; Alexander et al., 2006; Moberg et al., 2006). However, previous studies have shown differences in mean temperature changes within the basin, i.e., between its northern/southern and western/eastern parts (Xoplaki et al., 2003b), and the magnitude of the extreme temperature changes has also been shown to vary seasonally and regionally. Moreover, the changes are not always steady or monotonic. Thus, other studies have focused on particular subregions of the Mediterranean such as Spain (Brunet et al., 2007; Rodríguez-Puebla et al., 2010), Italy (Baldi et al., 2006; Bartolini et al., 2008; Toreti and Desiato, 2008), Eastern Mediterranean (Founda et al., 2004; Kostopoulou and Jones, 2005; Kuglitsch et al., 2010), and the Levant and northern parts of Egypt and Libya (Domroes and El-Tantawi, 2005; Zhang et al., 2005; Sensoy et al., 2007; El Kenawy et al., 2009).

In this study, the regional character of temperature changes across the Greater Mediterranean Region $\left(15^{\circ} \mathrm{W}-42^{\circ} \mathrm{E}\right.$, $25^{\circ} \mathrm{N}-50^{\circ} \mathrm{N}$ ) is examined with emphasis on trends since the mid-20th century in a number of indices of extremes (Sect. 3). In order to ensure reasonable sample size and robustness of analysis, the focus is on 'moderate' extremes defined by the 5th and 95th percentiles in the distribution of daily observations (and in one case by the 90th percentile). Fifteen (15) different indices of extremes have been calculated from daily maximum, minimum, and mean temperature, encompassing three different characteristics of extremes: their intensity, frequency, and duration (Sect. 2). While the global view of changes in daily temperature extremes over the 20th century is consistent with general warming (IPCC, 2007), the regional character of these

Published by Copernicus Publications on behalf of the European Geosciences Union. 
Table 1. Case-study domains (see also Fig. 1).

\begin{tabular}{|c|c|c|}
\hline Domain, Country & $\begin{array}{l}\text { Coordinates } \\
\text { of domain centre }\end{array}$ & Character \\
\hline Athens, Greece & $23.80^{\circ} \mathrm{E} 38.03^{\circ} \mathrm{N}$ & Urban \\
\hline Beirut, Lebanon & $35.51^{\circ} \mathrm{E} 33.79^{\circ} \mathrm{N}$ & Urban \\
\hline Alexandria/West Nile Delta, Egypt & $29.88^{\circ} \mathrm{E} 31.13^{\circ} \mathrm{N}$ & Urban/Coastal \\
\hline Tuscany, Italy & $11.00^{\circ} \mathrm{E} 43.50^{\circ} \mathrm{N}$ & Rural \\
\hline Apulia, Italy & $16.75^{\circ} \mathrm{E} 40.75^{\circ} \mathrm{N}$ & Rural \\
\hline Judean Foothills, Israel & $34.75^{\circ} \mathrm{E} 31.25^{\circ} \mathrm{N}$ & Rural \\
\hline Tel Hadya, Syria & $36.50^{\circ} \mathrm{E} 36.00^{\circ} \mathrm{N}$ & Rural \\
\hline Gulf of Valencia, Spain & $0.38^{\circ} \mathrm{W} 39.38^{\circ} \mathrm{N}$ & Coastal \\
\hline Gulf of Oran, Algeria & $0.63^{\circ} \mathrm{W} 35.63^{\circ} \mathrm{N}$ & Coastal \\
\hline Gulf of Gabès, Tunisia & $10.50^{\circ} \mathrm{E} 34.75^{\circ} \mathrm{N}$ & Coastal \\
\hline
\end{tabular}

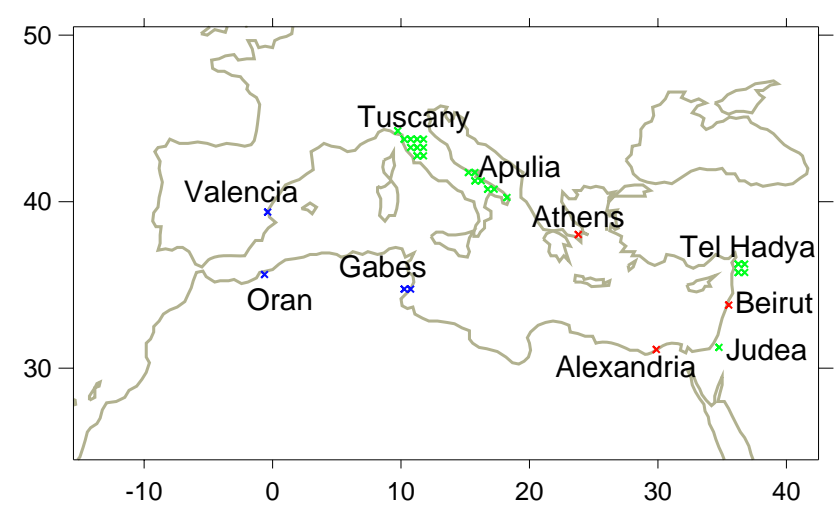

Fig. 1. Geographical locations of case-study domains. Red/Green/Blue: Urban/Rural/Coastal case-study domains (see Table 1).

changes should be modulated by large-scale climatic patterns manifested in, inter alia, atmospheric circulation (Kenyon and Hegerl, 2008). Thus, potential relationships between Mediterranean temperature extremes and large-scale atmospheric circulation are also examined (Sect. 4). Two recently available gridded temperature datasets encompassing the Mediterranean are analysed (one station-based and the other based on reanalysis - see Sect. 2). As well as considering changes across the entire region, particular consideration is given to a set of 10 case-study domains scattered across the Mediterranean, which encompass urban, rural, and coastal locations (see Fig. 1 and Table 1). These case-study domains are the subject of integrated assessment in the European Union funded CIRCE project, and one of the criteria for their selection is their vulnerability to climate change and variability, including extreme events (http: //www.cru.uea.ac.uk/projects/circe/index.html).

\section{Temperature and atmospheric circulation data and indices}

One of the two temperature data sets analysed is the E-OBS dataset of gridded daily minimum, maximum, and mean surface air temperatures (TN, TX, and TG) over Europe and the circum-Mediterranean countries for the period 1950-2009 (Haylock et al., 2008). This dataset was produced by spatial interpolation and kriging of daily observations (station data). E-OBS version 2.0 on a 0.5 degree regular latitude/longitude grid was used to derive indices of extremes for the overall Mediterranean region, while for some of the selected geographical domains (Table 1) data from finer-resolution grids ( 0.25 degree regular and 0.22 degree rotated-polar grids) were also selected. The spatial and temporal coverage of EOBS is determined by the availability of the underlying station data, which is quite limited in the southern and eastern areas of the Mediterranean Basin (i.e., N. Africa and Middle East). The gridded temperature fields suffer from large gaps here, which substantially restrict their potential for studying temperature variability in these regions. In addition to EOBS, daily TN, TX, and TG data from the ERA-40 reanalysis project (Uppala et al., 2005) and the more recent ERAInterim system (Simmons et al., 2006) were analysed. These two data assimilation products were merged after adjusting and re-interpolating the 1957-1988 ERA-40 data (1.0 degree grid) against the ERA-Interim data (1.5 degree grid) using multiple regression over the common years 1989-2002. The merged dataset is hereafter referred to as "ERA-40".

The advantages of E-OBS are its higher spatial resolution (50 km - compared with 1-1.5 degrees latitude/longitude for the reanalysis) and its direct use of station data. However, station coverage varies over time and, as noted above, is limited in parts of the domain. Thus, the continuous temporal and spatial (over both land and sea) coverage of the reanalysis and the dynamic consistency between the variables make the latter a valuable complementary source for studying spatial and temporal variations in temperature extremes. 
Table 2. Indices of temperature extremes.

\begin{tabular}{lll}
\hline Abbr. & Index description & Parameter \\
\hline Intensity-related indices & \\
\hline TN5p & Threshold of extremely cold min temperature & 5th percentile of daily minimum temperature (TN) \\
TN95p & Threshold of extremely warm min temperature & 95th percentile of daily minimum temperature \\
TX5p & Threshold of extremely cold max temperature & 5th percentile of daily maximum temperature (TX) \\
TX95p & Threshold of extremely warm max temperature & 95th percentile of daily maximum temperature \\
TG5p & Threshold of extremely cold mean temperature & 5th percentile of daily mean temperature (TG) \\
TG95p & Threshold of extremely warm mean temperature & 95th percentile of daily mean temperature \\
\hline Frequency-related indices & \\
\hline TN5n & Frequency of very cold nights & Number of days with TN falling below TN5p \\
TN95n & Frequency of very warm nights & Number of days with TN exceeding TN95p \\
TX5n & Frequency of very cold days & Number of days with TX falling below TX5p \\
TX95n & Frequency of very warm days & Number of days with TX exceeding TX95p \\
TG5n & Frequency of very cold daily means & Number of days with TG falling below TG5p \\
TG95n & Frequency of very warm daily means & Number of days with TG exceeding TG95p \\
\hline Duration-related indices & \\
\hline CWDI & Cold Wave Duration Index & Number of consecutive days with TN below TN5p \\
WSDI & Warm Spell Duration Index & Number of consecutive days (at least six) with TX exceeding TX90p \\
HWDI & Heat Wave Duration Index & Number of consecutive days with TX exceeding TX95p \\
\hline
\end{tabular}

Fifteen indices of temperature extremes were calculated to study the intensity, frequency, and duration of extreme events (see Table 2) on a seasonal basis for each grid-point of the EOBS and ERA-40 datasets. The 1961-1990 base-line period was used to define the thresholds. In the case of the E-OBS indices, for the domains of Beirut, Alexandria, Tel Hadya, and Gulf of Gabès, some years in the 1960s were occasionally excluded from the standard base-line period due to missing data. The thresholds used are percentile-based for 5-day running windows centred on each calendar day, although the window length can expand (from 5 days up to 1 month) when there are missing data (in the case of E-OBS) in order to have $99 \%$ of the total number of days in the base-line period with valid data. Having estimated the thresholds (intensity-related indices), the calculation of frequency and duration-related indices was made on the condition (for E-OBS) that no more than three missing values were found within a three-month season. For the case-study domains that comprise more than one grid-point (i.e., Tuscany, Apulia, Tel Hadya, Gulf of Gabès - see Table 1), the indices are calculated as the average of the indices for the individual grid points.

The potential influence of large-scale atmospheric circulation on temperature extremes was studied by comparing indices of well-documented, major atmospheric circulation patterns in the Euro-Atlantic domain with the indices of extremes (see Sect. 4). Circulation indices were selected based on a review of the relevant literature.

In Europe, large-scale atmospheric patterns are known to drive inter-annual variations of seasonal-mean temperatures over winter, and also - albeit modestly - in summer. The North Atlantic Oscillation (NAO) predominantly influ- ences winter temperatures, though differently in northwest and southeast regions of the Europe-Mediterranean domain (Hurrell and van Loon, 1997). Extremes of temperature are also affected likewise: changes of opposite sign are observed north/south of $40^{\circ} \mathrm{N}$ in Europe (Scaife et al., 2008; Kenyon and Hegerl, 2008). In the Mediterranean region, the socalled Mediterranean Oscillation (MO) (Conte et al., 1989; Palutikof et al., 1996) is linked to a northwest to southeast temperature gradient across the basin. The reported influence of circulation patterns varies across the Mediterranean Basin. Over the Iberian Peninsula, cold extremes have been found to be associated with the East Atlantic (EA) pattern, whereas warm extremes have been associated with the Scandinavia (SCAND) teleconnection pattern (Rodríguez-Puebla et al., 2010). In the Western Mediterranean, blocking conditions favour high summer temperatures (Xoplaki et al., 2003b). For individual summer months, warm extremes over the Western-Central Mediterranean are associated with weak blockings in June and with a baroclinic pattern of anomalies in July and August, probably related with the regional shifts of the descending branch of the Hadley circulation (Carril et al., 2007). In the Central Mediterranean, summer extremes have been related to the position of the Mediterranean branch of the westerly jet stream over the Euro-Atlantic area (Baldi et al., 2006). In the Eastern Mediterranean, nearbydeveloping and northwest European pressure patterns are both shown to contribute to the development of extremes in winter (Kutiel et al., 2002; Hatzaki et al., 2009; Founda and van Loon, 2008) and summer (Xoplaki et al., 2003a; 2003b; Kostopoulou and Jones, 2007b; Folland et al., 2009). 
Extremes' indices: E-OBS vs. ERA-40 data

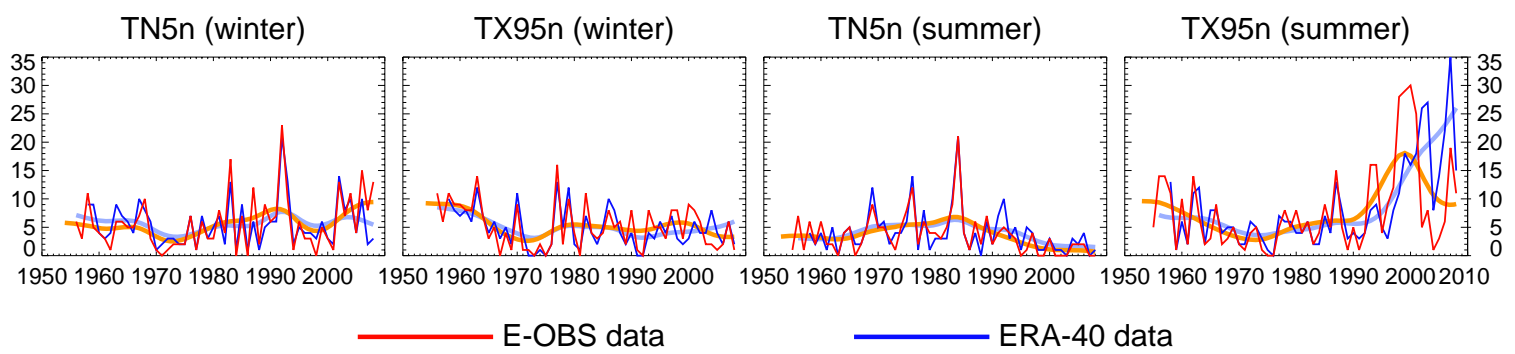

Fig. 2. Comparison of TN5n and TX95n extreme temperature indices for Athens domain based on E-OBS and ERA-40 temperature data.

Based on this review, two indices of the NAO were selected (one defined from SLP, the other from 500mb geopotential height), together with MO and Arctic Oscillation (AO) indices, and also five mid-tropospheric circulation indices: SCAND, EA, East Atlantic/West Russia Pattern (EA/WR), North Sea - Caspian Pattern (NCP, Kutiel et al., 2002), and Eastern Mediterranean Pattern (EMP, Hatzaki et al., 2009). The latter two are considered to be winter-dominant patterns and thus were only analysed for this season.

A list of the selected atmospheric circulation indices, their description and the web addresses (or calculation method) of the specific data sets used are all provided in Table 3 . The indices are not independent of each other. Some exhibit statistically significant inter-correlations (Table 4), since they describe atmospheric patterns which partly overlap and share some common time variability. It is not surprising that in winter, the two MO indices $(r=0.91)$, and also the SLPbased NAO-CRU and AO $(r=0.81)$ indices are highly positively correlated with each other. The mid-tropospheric defined NAO-CPC is also positively correlated with its SLPdefined NAO-CRU counterpart $(r=0.57)$. The various NAO, $\mathrm{AO}$ and $\mathrm{MOI}$ indices all have significant positive correlations with each other. The NCP index is positively correlated with EA/WR, MOI-1, and AO, while the EMP index is significantly negatively correlated with EA. The only other significant negative correlations in winter are associated with the SCAND index. In summer, the circulation indices intercorrelations are much weaker (Table 4), although the two MOI indices, together with the AO and NAO indices, again have significant positive correlations. The two MOI indices are negatively correlated with the SNAO index - significantly so in the case of MOI-2.

\section{Trends in the indices of temperature extremes}

There is general agreement between the indices of extremes calculated from E-OBS and ERA-40 data, leading to similar large-scale patterns in their trends (as shown later on in this section), though local discrepancies are not always small, which holds true for the case study-domains too (see
Fig. 2). The latter discrepancies arise from two additional factors: (a) the different grids and resolutions characterizing the two datasets, which means that the selected grid-points are not co-located; and (b) the limited number of station observations in northeast Africa and the Middle East used for developing and interpolating E-OBS, which means that some series (e.g., for Alexandria) are biased towards nearby dataricher areas. In general, however, the availability of the two datasets facilitates identification of the more robust changes.

Linear trends based on ordinary least square fits were estimated for the whole common data period (1958-2008) and for the most recent two decades (1989-2008). Trends for the case-study domains calculated from E-OBS are summarised in Tables 5 and 6 for winter and summer, respectively, while Mediterranean-wide maps for selected indices calculated from both E-OBS and ERA-40 are shown in Figs. 3 and 4 for 1958-2008 (TN5n and TX95n, respectively) and for 1989-2008 (HWDI) in Fig. 5.

Trends in winter vary across the Mediterranean and depend on the period studied. For the 1958-2008 period, a general decrease of cold extremes is found in the western and central Mediterranean, whereas a contrasting increase dominates in the eastern Mediterranean. Warm extremes are consistently increasing everywhere, except in the eastern part of the basin. For the recent 1989-2008 period, a near reversal of these trends is observed, though most prominently in the eastern basin. In addition to these broad-scale patterns for the two periods studied, a noticeable variability in strength, statistical significance, and occasionally in sign of trend is also observed locally. In particular:

- Most of the trends in cold extremes (including all trends for the 1989-2008 period) are not statistically significant. Some significant decreasing long-term trends (i.e., over the period 1958-2008) are found for the Gulf of Valencia, and also for the easterly Alexandria casestudy domain. Increasing long-term trends are significant for Athens, Tel Hadya, and the Gulf of Oran casestudy domains (trends for the latter domain contrast with the general warming trends in the western Mediterranean). 
Table 3. Atmospheric circulation indices.

\begin{tabular}{|c|c|c|}
\hline Abbr. & Circulation index description and source & Parameter \\
\hline NAO-CRU & $\begin{array}{l}\text { North Atlantic Oscillation index, based on Gibraltar to Iceland normalised station } \\
\text { sea-level pressure (SLP) difference. (http://www.cru.uea.ac.uk/cru/data/nao.htm) }\end{array}$ & SLP \\
\hline $\mathrm{AO}$ & $\begin{array}{l}\text { Arctic Oscillation index: based on the time evolution of the Northern Mid-latitude } \\
\text { to Polar SLP difference, as derived from Northern Hemisphere SLP Empirical Or- } \\
\text { thogonal Function (EOF) analysis. } \\
\text { (http://www.cpc.ncep.noaa.gov/products/precip/CWlink/daily_ao_index/ao.shtml) }\end{array}$ & SLP \\
\hline SNAO & $\begin{array}{l}\text { Summer North Atlantic Oscillation index, based on the amplitude of the North } \\
\text { Sea-centred SLP pattern in JJA, which is the principal EOF pattern of inter-annual } \\
\text { SLP variability in the European domain; derived from the Hadley Centre HadSLP2r } \\
\text { dataset analysis. (http://hadobs.metoffice.com/hadslp2/) }\end{array}$ & SLP \\
\hline MOI-1/2 & $\begin{array}{l}\text { Mediterranean Oscillation index, based on normalised SLP difference between } \\
\text { Algiers and Cairo (MOI-1), or Gibraltar and Israel (MOI-2), based on NCEP/NCAR } \\
\text { reanalysis SLP data (Kalnay et al., 1996, Kistler at al., 2001). } \\
\text { (http://www.cru.uea.ac.uk/cru/data/moi/) }\end{array}$ & SLP \\
\hline $\mathrm{NAO}-\mathrm{CPC}$ & $\begin{array}{l}\text { North Atlantic Oscillation index, one of the Northern Hemisphere teleconnection } \\
\text { indices derived from mid-tropospheric geopotential height }(500 \mathrm{mb}) \text { EOF analysis } \\
\text { of CPC/NOAA. (http://www.cpc.ncep.noaa.gov/data/teledoc/telecontents.shtml) }\end{array}$ & $\begin{array}{l}\text { 500-mb geopotential } \\
\text { height (g.h.) }\end{array}$ \\
\hline EA & East Atlantic Pattern, as above from CPC/NOAA. & 500-mb g.h. \\
\hline $\mathrm{EA} / \mathrm{WR}$ & East Atlantic/West Russia Pattern, as above from CPC/NOAA. & 500-mb g.h. \\
\hline SCAND & Scandinavia Pattern, as above from CPC/NOAA. & 500-mb g.h. \\
\hline NCP & $\begin{array}{l}\text { North Sea - Caspian Pattern index: } 500-\mathrm{mb} \text { geopotential height difference between } \\
\text { the regions of North Sea and Caspian Sea; calculation is based on NCEP-NCAR } \\
\text { reanalysis data, as in Kutiel and Benaroch (2002). Winter only. }\end{array}$ & 500-mb g.h. \\
\hline EMP & $\begin{array}{l}\text { Eastern Mediterranean Pattern index: } 500 \text {-mb geopotential height difference } \\
\text { between NE Atlantic }\left(52.5^{\circ} \mathrm{N}, 25.0^{\circ} \mathrm{W}\right) \text { and NE Africa }\left(32.5^{\circ} \mathrm{N}, 22.5^{\circ} \mathrm{E}\right) \text {; } \\
\text { calculation is based on NCEP-NCAR reanalysis data, as in Hatzaki et al. (2007). } \\
\text { Winter only. }\end{array}$ & 500-mb g.h. \\
\hline
\end{tabular}

Table 4. Statistically significant correlations for the period 1958-2008 between the circulation indices.

\begin{tabular}{|c|c|c|c|c|c|c|c|}
\hline Winter DJF & $\mathrm{AO}$ & NAO-CRU & NAO-CPC & EA & EA/WR & SCAND & MOI-1 \\
\hline NAO-CRU & $0.81 * *$ & & & & & & \\
\hline NAO-CPC & $0.57 * *$ & $0.57 * *$ & & & & & \\
\hline SCAND & $-0.38^{*}$ & $-0.39 *$ & & & & & \\
\hline MOI-1 & $0.75^{* *}$ & $0.82 * *$ & $0.53 * *$ & & & $-0.53 * *$ & \\
\hline MOI-2 & $0.64 * *$ & $0.86^{* *}$ & $0.52 * *$ & & & $-0.53 * *$ & $0.91 * *$ \\
\hline $\mathrm{NCP}$ & $0.57 * *$ & & & & $0.60 * *$ & & $0.40^{*}$ \\
\hline EMP & & & & $-0.47 * *$ & & & \\
\hline Summer JJA & SNAO & $\mathrm{AO}$ & $\mathrm{I}-1$ & & & & \\
\hline NAO-CRU & & $0.42 *$ & & & & & \\
\hline NAO-CPC & & $0.37 *$ & & & & & \\
\hline MOI-2 & $-0.40 *$ & & $8 * *$ & & & & \\
\hline
\end{tabular}

* significant at the $99 \%$ level. ** significant at the $99.99 \%$ level. 
TN5n trends (1958-2008)
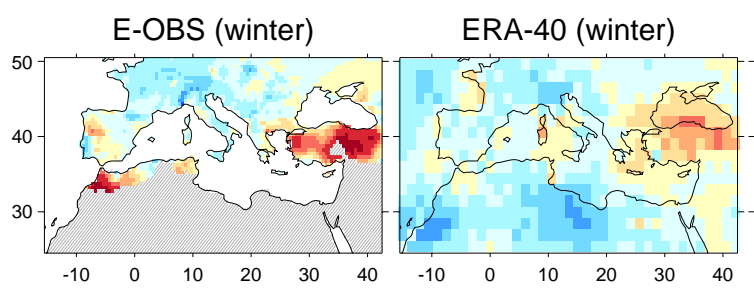

E-OBS (summer)

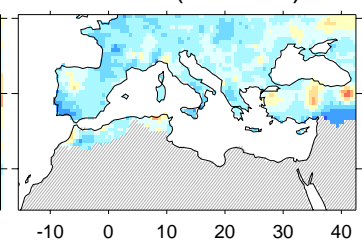

significant-only trends
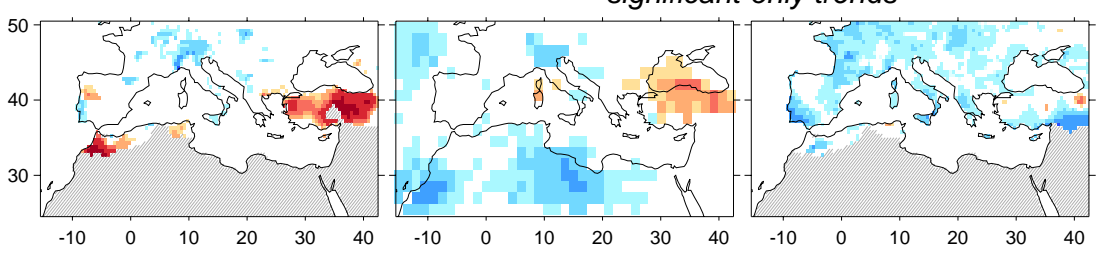

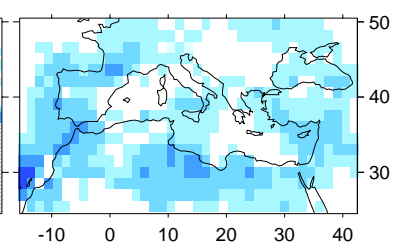

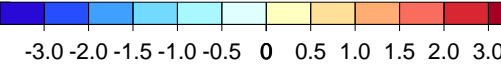

Fig. 3. Trends of winter (left-hand columns) and summer (right-hand columns) TN5n (days per decade), over the period 1958-2008, from E-OBS and ERA-40 data. The lower panel shows only statistically-significant trends. Gray-shaded areas in E-OBS trend maps correspond to grid-points with missing years in the 1961-1990 base-line period (or with no data at all).

TX95n trends (1958-2008)
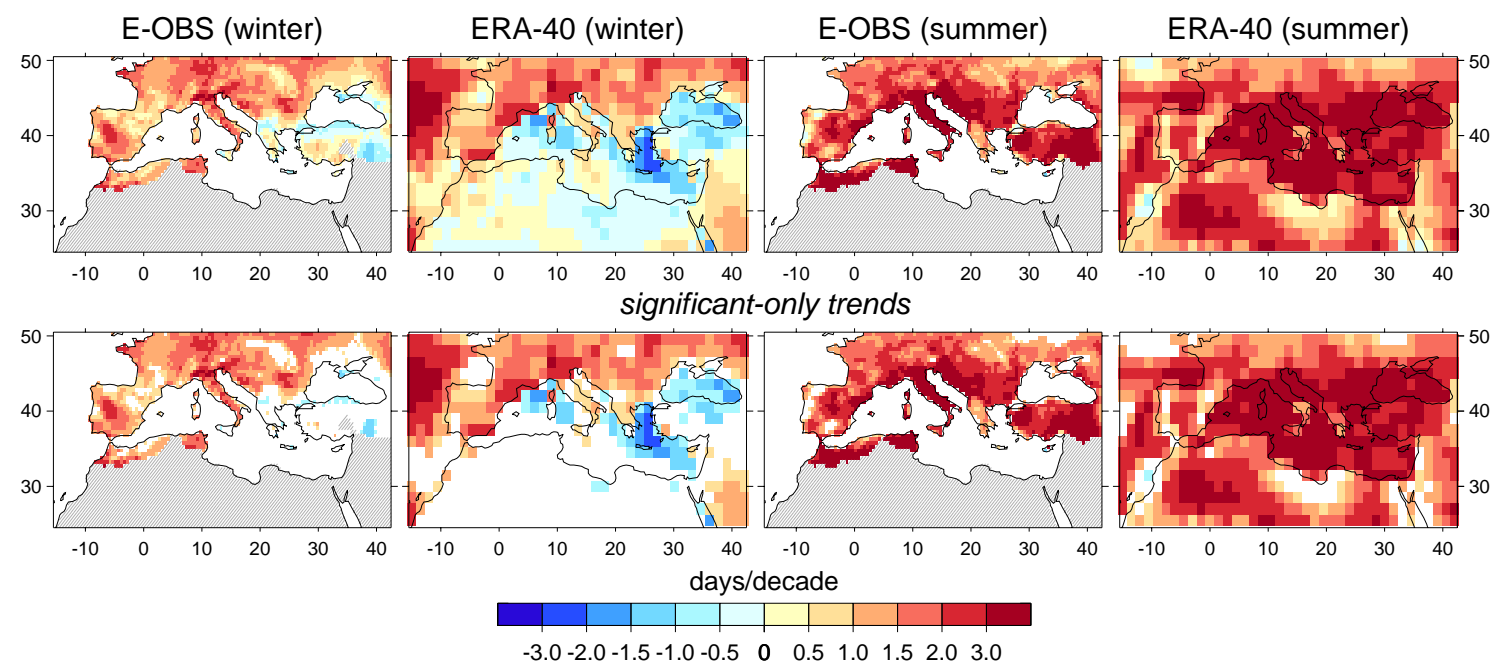

Fig. 4. Trends of winter (left-hand columns) and summer (right-hand columns) TX95n (days per decade), over the period 1958-2008, from E-OBS and ERA-40 data. The lower panel shows only statistically-significant trends.

- Significant increasing trends in warm extremes are found in the northern Mediterranean. Day-time warm extremes (TX95n, WSDI, HWDI) exhibit stronger trends than the night-time ones (TN95n).

In summer, in contrast, trends exhibit a rather more uniform character: reduction of cold extremes and enhancement of hot extremes is observed almost everywhere, although trends are not always statistically significant. Some diversity in trends is nevertheless found:
- The reduction in frequency and duration of cold extremes (TN5n, TX5n, and TG5n) is most pronounced in the southeast Mediterranean (i.e., in the Beirut, Alexandria, Judean Foothills, and Tel Hadya case-study domains).

- The increase in frequency of hot extremes is higher for night-time (TN95n) than for day-time indices (TX95n). For TX95n, in particular, increases are most pronounced for the Italian case-study domains (i.e., Tuscany and Apulia). 
Table 5. For each extreme, trends over 1958-2008 (left column) and 1989-2008 (right column) are given.

\begin{tabular}{|c|c|c|c|c|c|c|c|c|c|c|c|c|c|c|c|c|c|c|}
\hline \multirow{2}{*}{$\begin{array}{l}\text { Domain } \\
\text { Athens }\end{array}$} & \multicolumn{2}{|c|}{ TN5n } & \multicolumn{2}{|c|}{ TX5n } & \multicolumn{2}{|c|}{ TG5n } & \multicolumn{2}{|c|}{ TN95n } & \multicolumn{2}{|c|}{ TX95n } & \multicolumn{2}{|c|}{ TG95n } & \multicolumn{2}{|c|}{ CWDI } & \multicolumn{2}{|c|}{ WSDI } & \multicolumn{2}{|c|}{ HWDI } \\
\hline & 0.8 & 1.3 & 0.8 & -0.3 & 0.7 & 1.4 & 0.0 & 1.3 & -0.5 & -0.8 & -0.4 & 0.6 & 0.0 & 0.2 & -0.1 & -0.1 & -0.2 & 0.2 \\
\hline Beirut & -0.3 & -1.6 & 0.0 & -3.9 & 0.0 & -2.6 & 0.4 & 0.4 & 0.9 & 4.0 & 1.1 & 2.1 & 0.0 & -0.2 & 0.8 & 1.9 & 0.4 & 1.7 \\
\hline Alexandria & -1.2 & -2.8 & -0.1 & -3.4 & -0.6 & -3.0 & 1.9 & 3.6 & -0.8 & 2.0 & 1.1 & 3.5 & -0.4 & -0.6 & -0.2 & 1.0 & -0.2 & 0.9 \\
\hline Tuscany & 0.0 & -0.3 & -0.5 & 1.1 & -0.4 & -0.4 & 0.8 & 2.7 & 1.5 & -1.8 & 0.7 & 1.4 & 0.0 & -0.5 & 0.5 & -1.0 & 0.5 & -0.7 \\
\hline Apulia & -0.3 & -0.4 & -0.2 & 0.9 & -0.3 & 0.2 & 0.2 & 3.0 & 0.7 & 2.1 & 0.3 & 2.9 & -0.2 & -0.3 & 0.4 & 1.0 & 0.3 & 0.5 \\
\hline Judean Foothills & -0.3 & -1.5 & -0.1 & -3.4 & 0.1 & -3.2 & 0.8 & 2.1 & 0.2 & 1.8 & 0.4 & 0.5 & 0.1 & -0.2 & 0.5 & 1.5 & 0.2 & 0.9 \\
\hline Tel Hadya & 1.3 & 2.9 & 0.6 & -1.7 & 0.7 & -0.2 & -0.6 & -1.0 & 0.5 & 2.5 & -0.1 & 0.8 & 0.7 & 1.2 & 0.5 & 1.7 & 0.4 & 1.7 \\
\hline Gulf of Valencia & -0.6 & -0.5 & -0.7 & 0.2 & -0.8 & 0.7 & 0.8 & 0.3 & 1.1 & 1.8 & 1.1 & 1.8 & -0.1 & -0.4 & 0.3 & 0.3 & 0.3 & 0.3 \\
\hline Gulf of Oran & 1.1 & 0.5 & 0.0 & 0.5 & 0.5 & 1.4 & 0.3 & 0.6 & 0.7 & -0.4 & 0.3 & -0.7 & 0.2 & -0.2 & 0.5 & -0.3 & 0.2 & 0.2 \\
\hline Gulf of Gabès & 0.1 & -0.6 & -0.7 & -1.0 & -0.4 & -0.4 & -1.0 & 1.0 & 1.3 & 1.0 & -0.2 & 0.3 & 0.2 & -0.1 & 0.7 & 1.0 & 0.6 & 0.8 \\
\hline
\end{tabular}

Table 6. Trends of indices of extremes, as in Table 4, but for summer (JJA).

\begin{tabular}{|c|c|c|c|c|c|c|c|c|c|c|c|c|c|c|c|c|c|c|}
\hline \multirow{2}{*}{$\begin{array}{l}\text { Domain } \\
\text { Athens }\end{array}$} & \multicolumn{2}{|c|}{ TN5n } & \multicolumn{2}{|c|}{ TX5n } & \multicolumn{2}{|c|}{ TG5n } & \multicolumn{2}{|c|}{ TN95n } & \multicolumn{2}{|c|}{ TX95n } & \multicolumn{2}{|c|}{ TG95n } & \multicolumn{2}{|c|}{ CWDI } & \multicolumn{2}{|c|}{ WSDI } & \multicolumn{2}{|c|}{ HWDI } \\
\hline & -0.7 & -1.9 & -0.7 & 0.2 & -0.8 & -1.0 & 4.9 & 12.8 & 2.0 & 3.4 & 3.4 & 7.9 & -0.3 & -1.2 & 0.9 & 0.8 & 0.5 & 1.1 \\
\hline Beirut & -2.4 & -0.5 & -1.5 & -2.3 & -2.0 & -1.5 & 5.0 & 6.8 & 0.9 & 4.1 & 3.7 & 7.6 & -0.6 & -0.4 & 0.4 & 1.3 & 0.2 & 1.1 \\
\hline Alexandria & -2.5 & -1.3 & 1.5 & -6.1 & -1.2 & -5.0 & 7.2 & 12.2 & -1.9 & 1.4 & 2.5 & 7.8 & -0.6 & -0.6 & -0.8 & 0.3 & -0.3 & 0.6 \\
\hline Tuscany & -0.2 & -0.5 & -0.8 & -0.6 & -0.5 & -0.3 & 3.4 & 9.2 & 4.1 & 10.7 & 4.1 & 10.8 & -0.1 & -0.3 & 1.8 & 5.6 & 1.7 & 5.6 \\
\hline Apulia & -0.8 & 0.7 & -0.9 & 0.5 & -0.9 & 0.3 & 4.6 & 11.0 & 4.2 & 7.9 & 4.9 & 11.1 & -0.3 & 0.4 & 1.5 & 3.0 & 1.2 & 2.3 \\
\hline Judean Foothills & -1.9 & -0.9 & -1.2 & -2.5 & -1.3 & -2.5 & 7.7 & 21.1 & 2.6 & 7.1 & 5.7 & 17.4 & -0.4 & -0.6 & 1.4 & 3.8 & 1.2 & 3.3 \\
\hline Tel Hadya & -1.9 & -0.4 & -2.3 & -1.3 & -2.2 & -0.8 & 7.0 & 6.8 & 3.3 & 5.4 & 5.4 & 8.4 & -0.6 & -0.3 & 1.5 & 1.8 & 1.2 & 1.5 \\
\hline Gulf of Valencia & -1.0 & -1.1 & -0.8 & 0.2 & -1.0 & -0.6 & 8.8 & 16.8 & 2.5 & 2.8 & 6.6 & 8.9 & -0.4 & -0.7 & 1.1 & 2.0 & 0.8 & 1.2 \\
\hline Gulf of Oran & 0.3 & -0.6 & -0.7 & -1.6 & -0.2 & -2.4 & 1.6 & 0.3 & 2.0 & 1.3 & 2.3 & 0.5 & 0.2 & -0.2 & 0.5 & -0.1 & 0.4 & -0.3 \\
\hline Gulf of Gabès & -0.6 & -0.5 & -1.0 & 0.3 & -0.6 & -0.8 & 4.7 & 10.7 & 2.8 & 5.4 & 3.1 & 8.0 & -0.2 & -0.3 & 1.2 & 2.1 & 0.9 & 1.6 \\
\hline
\end{tabular}

- The elongation of warm/hot spells (WSDI and HWDI) is most pronounced for inland case-study domains (i.e., for Tuscany, Apulia, Judean Foothills, and Tel Hadya).

Warming trends in summer (prominent in the warm/hot indices of extremes, i.e., TN95n, TX95n, WSDI, and HWDI) seem to have intensified over the more recent 1989-2008 period. These increasing trends of hot extremes over the last $20 \mathrm{yr}$ are particularly strong over the Central and Eastern Mediterranean and also in the Black Sea region. This intensification of warming trends is consistent with earlier studies of temperature extremes for Italy that indicate a change point between the end of the 1970s and beginning of the 1980s (Bartolini et al., 2008; Toreti and Desiato, 2008). Potential causes of the enhanced trends are discussed in Sects. 4 and 5.

\section{Relationships between temperature extremes and large-scale atmospheric circulation}

Relationships between the indices of extremes (Table 2) for the 10 case-study domains (Table 1) calculated from E-OBS and selected large-scale atmospheric circulation indices (Table 3) were explored using regression analysis (variance explained) supported by Spearman and Pearson correlation analysis. It was decided to use E-OBS rather than ERA-40 indices of extremes, since the former are directly based on station data and the CIRCE case-study locations (Fig. 1) are all land-based. The primary aim of this study is to identify those specific circulation indices which may have some influence on the occurrence of extremes, and how these relationships may vary depending on the type of extreme considered as well as regionally and seasonally. The aim, at least at this stage, is not to construct a predictive statistical model. Thus, the full data period is used to construct the regressions - rather than using split calibration/validation periods or cross-validation.

Circulation indices which appear to have potential influence on the occurrence of extremes are summarised in Tables 7 and 8 for winter and summer, respectively. In order to appear in these tables, circulation indices have to meet the following three criteria:

- explain $\geq 10 \%$ of an index of extremes variance (unfiltered time series)

- explain $\geq 10 \%$ of an index of extremes variance (highpass filtered time series)

- exceed the $95 \%$ significance level criterion using Spearman rank correlation.

The second criterion screens for inflated values of the variance explained due to the presence of common low-frequency components or trends. It thus focuses on those 
Table 7. Relationships between indices of temperature extremes calculated from E-OBS and atmospheric circulation indices in winter (DJF) for the period 1958-2008. Only circulation indices that explain $\geq 10 \%$ of an index of extremes time variance in both un-filtered and filtered time series and that have Spearman correlations which are significant at the $95 \%$ level appear in the table. Indices that explain $\geq 40 \%$ of variance are shown in bold. Best-associated circulation indices are ordered first in each cell. NAO and MOI denote that both versions (NAO-CRU/NAO-CPC and MOI-1/MOI-2, respectively - see Table 3) are associated with the respective index of extremes.

\begin{tabular}{|c|c|c|c|c|c|c|c|c|c|}
\hline Domain & TN5n & TX5n & TG5n & TN95n & TX95n & TG95n & CWDI & WSDI & HWDI \\
\hline Athens & $\begin{array}{l}\text { EA/WR } \\
\text { MOI-1 } \\
\text { NCP } \\
\text { EMP }\end{array}$ & $\begin{array}{l}\text { NCP } \\
\text { EA/WR } \\
\text { EMP } \\
\text { EA }\end{array}$ & $\begin{array}{l}\text { EMP } \\
\text { NCP } \\
\text { EA/WR }\end{array}$ & $\begin{array}{l}\text { NCP } \\
\text { AO } \\
\text { MOI } \\
\text { NAO-CRU }\end{array}$ & $\begin{array}{l}\text { NCP } \\
\text { MOI } \\
\mathrm{AO} \\
\text { EMP }\end{array}$ & $\begin{array}{l}\text { AO } \\
\text { MOI } \\
\text { NCP } \\
\text { NAO-CRU } \\
\text { EMP }\end{array}$ & EA/WR & $\begin{array}{l}\text { AO } \\
\text { EMP } \\
\text { MOI } \\
\text { NCP } \\
\text { NAO-CPC }\end{array}$ & $\begin{array}{l}\text { NCP } \\
\text { AO } \\
\text { MOI } \\
\text { EMP }\end{array}$ \\
\hline Beirut & $\begin{array}{l}\text { NCP } \\
\text { EA/WR } \\
\text { AO }\end{array}$ & $\begin{array}{l}\text { NCP } \\
\text { EA/WR } \\
\text { MOI-1 }\end{array}$ & $\begin{array}{l}\text { NCP } \\
\text { EA/WR } \\
\text { AO } \\
\text { MOI-1 }\end{array}$ & $\begin{array}{l}\text { NAO } \\
\text { NCP } \\
\mathrm{AO}\end{array}$ & $\begin{array}{l}\text { NAO } \\
\text { MOI-1 } \\
\text { NAO-CRU } \\
\text { AO }\end{array}$ & $\begin{array}{l}\text { NCP } \\
\text { MOI-1 } \\
\text { NAO-CRU } \\
\text { AO }\end{array}$ & $\begin{array}{l}\text { NCP } \\
\text { EA/WR } \\
\text { AO }\end{array}$ & & \\
\hline Alexandria & $\begin{array}{l}\text { NCP } \\
\text { AO } \\
\text { EA/WR } \\
\text { NAO-CRU }\end{array}$ & $\begin{array}{l}\text { NCP } \\
\text { EA/WR } \\
\text { MOI-1 } \\
\text { AO } \\
\text { EMP }\end{array}$ & $\begin{array}{l}\text { NCP } \\
\text { EA/WR } \\
\text { AO } \\
\text { MOI-1 } \\
\text { NAO-CRU }\end{array}$ & & $\begin{array}{l}\text { NAO } \\
\text { AO } \\
\text { MOI }\end{array}$ & $\begin{array}{l}\text { NAO-CRU } \\
\text { AO }\end{array}$ & $\begin{array}{l}\text { NCP } \\
\text { EA/WR } \\
\text { AO } \\
\text { NAO-CRU }\end{array}$ & & \\
\hline Tuscany & $\begin{array}{l}\text { EMP } \\
\text { EA/WR }\end{array}$ & EMP & EMP & $\begin{array}{l}\text { EMP } \\
\text { EA/WR } \\
\text { NCP }\end{array}$ & $\begin{array}{l}\text { EA } \\
\text { EMP }\end{array}$ & EMP & $\begin{array}{l}\text { EA/WR } \\
\text { EMP }\end{array}$ & EA & EA \\
\hline Apulia & $\begin{array}{l}\text { EA/WR } \\
\text { EMP }\end{array}$ & EMP & $\begin{array}{l}\text { EMP } \\
\text { EA/WR }\end{array}$ & $\begin{array}{l}\text { MOI } \\
\text { NAO } \\
\text { AO } \\
\text { EMP } \\
\text { EA/WR } \\
\text { NCP }\end{array}$ & $\begin{array}{l}\text { EMP } \\
\text { NCP }\end{array}$ & $\begin{array}{l}\text { EMP } \\
\text { MOI } \\
\text { AO } \\
\text { NAO-CRU } \\
\text { EA/WR } \\
\text { NCP }\end{array}$ & EA/WR & EMP & EMP \\
\hline Judean Foothills & $\begin{array}{l}\text { NCP } \\
\text { AO } \\
\text { MOI } \\
\text { NAO-CRU } \\
\text { EA/WR }\end{array}$ & $\begin{array}{l}\text { NCP } \\
\text { EA/WR } \\
\text { AO } \\
\text { MOI-1 }\end{array}$ & $\begin{array}{l}\text { NCP } \\
\text { AO } \\
\text { EA/WR } \\
\text { MOI } \\
\text { NAO-CRU } \\
\text { SCAND }\end{array}$ & $\begin{array}{l}\text { NAO-CRU } \\
\text { AO }\end{array}$ & $\begin{array}{l}\text { MOI } \\
\text { NAO } \\
\mathrm{AO} \\
\mathrm{NCP}\end{array}$ & $\begin{array}{l}\text { NAO } \\
\text { AO } \\
\text { MOI-1 }\end{array}$ & $\begin{array}{l}\mathrm{AO} \\
\text { NCP } \\
\text { NAO-CRU } \\
\text { MOI }\end{array}$ & & NAO-CPC \\
\hline Tel Hadya & $\begin{array}{l}\text { NCP } \\
\text { EA/WR } \\
\text { MOI-1 } \\
\text { AO }\end{array}$ & $\begin{array}{l}\text { NCP } \\
\text { EA/WR } \\
\text { MOI-1 } \\
\text { AO }\end{array}$ & $\begin{array}{l}\text { NCP } \\
\text { EA/WR } \\
\text { MOI-1 } \\
\text { AO }\end{array}$ & $\begin{array}{l}\text { NAO } \\
\text { NCP } \\
\text { AO } \\
\text { EMP } \\
\text { MOI-1 } \\
\text { EA/WR }\end{array}$ & $\mathrm{NCP}$ & $\begin{array}{l}\text { NAO-CPC } \\
\text { NCP } \\
\text { AO } \\
\text { MOI-1 }\end{array}$ & $\begin{array}{l}\mathrm{NCP} \\
\mathrm{AO}\end{array}$ & & \\
\hline Gulf of Valencia & EMP & EMP & EMP & $\begin{array}{l}\text { EMP } \\
\text { EA/WR } \\
\text { NCP }\end{array}$ & $\begin{array}{l}\text { EMP } \\
\text { NCP }\end{array}$ & $\begin{array}{l}\text { EMP } \\
\text { NCP } \\
\text { EA/WR }\end{array}$ & EMP & $\begin{array}{l}\text { EMP } \\
\text { NCP }\end{array}$ & $\begin{array}{l}\text { EMP } \\
\text { NCP }\end{array}$ \\
\hline Gulf of Oran & $\begin{array}{l}\text { MOI } \\
\text { EMP } \\
\text { AO } \\
\text { NAO } \\
\text { SCAND }\end{array}$ & & $\begin{array}{l}\text { EMP } \\
\text { MOI } \\
\text { SCAND } \\
\text { NAO-CRU }\end{array}$ & $\begin{array}{l}\text { NAO } \\
\text { MOI } \\
\text { EMP } \\
\text { AO }\end{array}$ & $\begin{array}{l}\text { EMP } \\
\text { NCP } \\
\text { EA/WR }\end{array}$ & $\begin{array}{l}\text { EMP } \\
\text { MOI } \\
\text { NAO } \\
\text { AO }\end{array}$ & $\begin{array}{l}\text { MOI } \\
\text { AO } \\
\text { EMP } \\
\text { NAO } \\
\text { SCAND }\end{array}$ & EMP & EMP \\
\hline Gulf of Gabès & $\begin{array}{l}\text { EMP } \\
\text { MOI } \\
\text { NAO-CPC } \\
\text { SCAND }\end{array}$ & EMP & EMP & $\begin{array}{l}\text { NAO } \\
\text { MOI }\end{array}$ & $\begin{array}{l}\text { EMP } \\
\text { NAO-CRU } \\
\text { EA/WR }\end{array}$ & $\begin{array}{l}\text { NAO } \\
\text { MOI } \\
\text { EMP } \\
\text { AO }\end{array}$ & $\begin{array}{l}\text { MOI } \\
\text { EMP }\end{array}$ & $\begin{array}{l}\text { EMP } \\
\text { EA/WR }\end{array}$ & EMP \\
\hline
\end{tabular}


Table 8. Relationships between indices of temperature extremes and large-scale atmospheric circulation indices, as in Table 6, but for summer (JJA).

\begin{tabular}{|c|c|c|c|c|c|c|c|c|c|}
\hline Domain & TN5n & TX5n & TG5n & TN95n & TX95n & TG95n & CWDI & WSDI & HWDI \\
\hline \multirow[t]{2}{*}{ Athens } & & SNAO & SNAO & SNAO & SNAO & SNAO & & SNAO & \\
\hline & & NAO & & NAO & NAO & NAO-CPC & & & \\
\hline \multirow[t]{2}{*}{ Beirut } & EA/WR & & & SNAO & SNAO & SNAO & EA/WR & SNAO & SNAO \\
\hline & & & & NAO-CPC & $\mathrm{AO}$ & & & & \\
\hline Alexandria & & & EA & & & & NAO-CRU & & \\
\hline Tuscany & & & SNAO & & & & NAO-CPC & & \\
\hline \multirow[t]{2}{*}{ Apulia } & SNAO & SNAO & SNAO & SNAO & SNAO & SNAO & SNAO & SNAO & \\
\hline & & NAO-CRU & & & & & & & \\
\hline \multirow[t]{2}{*}{ Judean Foothills } & EA/WR & & NAO-CRU & & & NAO-CPC & NAO-CRU & & NAO-CRU \\
\hline & NAO-CRU & & & & & & EA/WR & & \\
\hline \multirow[t]{2}{*}{ Tel Hadya } & EA/WR & & & SNAO & SNAO & SNAO & & NAO-CPC & SNAO \\
\hline & & & & & & NAO-CPC & & SNAO & NAO-CPC \\
\hline \multicolumn{10}{|l|}{ Gulf of Valencia } \\
\hline \multicolumn{2}{|l|}{ Gulf of Oran } & & & & $\mathrm{AO}$ & & NAO-CRU & & \\
\hline Gulf of Gabès & NAO-CRU & NAO-CRU & $\begin{array}{l}\text { NAO-CRU } \\
\text { SCAND }\end{array}$ & NAO-CRU & & & NAO-CRU & & \\
\hline
\end{tabular}

circulation indices which also have some relationship with the high-frequency (i.e., interannual) component of the indices of extremes. The high-frequency filtering was implemented by removing the low-frequency (decadal-scale) component using a 15-year Gaussian filter. The third criterion was used to screen for inflated values of the variance explained due to the presence of outliers.

It is apparent from Tables 7 and 8 that (a) the influence of large-scale atmospheric circulation patterns is stronger in winter than in summer, as many past studies have shown; and (b) there is diversity in the associations of extreme temperatures with large-scale atmospheric patterns in both seasons, depending on domain, season, and the index of extremes considered. Some general features are evident, however, in the summary statistics presented in Table 9 . This table provides a count of the total number of relationships meeting the selection criteria for the most important circulation indices and for cold (TN5n, TX5n, TG5n) and warm/hot (TN95n, TX95n, TG95n) extremes. The sign of the relationships is also indicated.

For winter, there is no overall difference in the number of relationships found for warm or cold extremes, except for the cases of EA/WR and SCAND, which have more associations with cold extremes, and the NAO indices and AO which have more associations with warm extremes (Table 9). The relationships are consistently positive for cold extremes and negative for warm extremes - except in the case of SCAND which demonstrates negative relationships with cold extremes. These results are consistent with the correlations between the circulation indices - which are all positive
Table 9. Summary of the relationships identified in Table 7 (winter) and Table 8 (summer). The total number of times each circulation index appears is given for warm/cold (TN5n, TX5n, TG5n) and hot (TN95n, TX95n, TG95n) extremes together with the sign of the relationship (positive + or negative - ).

\begin{tabular}{lll}
\hline $\begin{array}{l}\text { Winter } \\
\text { DJF) }\end{array}$ & $\begin{array}{l}\text { Cold } \\
\text { extremes }\end{array}$ & $\begin{array}{l}\text { Warm } \\
\text { extremes }\end{array}$ \\
\hline NAO-CRU \& NAO-CPC & $1+$ & $9-$ \\
NAO-CRU & $6+$ & $10-$ \\
NAO-CPC & $1+$ & 0 \\
AO & $12+$ & $17-$ \\
EA/WR & $18+$ & $8-$ \\
SCAND & $6-$ & 0 \\
MOI-1 \& MOI-2 & $6+$ & $11-$ \\
MOI-1 & $8+$ & $6-$ \\
NCP & $15+$ & $17-$ \\
EMP & $18+$ & $14-$ \\
\hline Summer & Cold & Warm/ \\
(JJA) & extremes & hot extremes \\
\hline NAO-CRU \& NAO-CPC & $1+$ & $2-$ \\
NAO-CRU & $6+$ & $1-$ \\
NAO-CPC & 0 & $4-$ \\
EA/WR & $3+$ & 0 \\
SNAO & $6+$ & $12-$ \\
\hline
\end{tabular}


except in cases involving SCAND and the case of EMP/EA (Table 4). The issue of whether the sign of the relationships makes sense from the perspective of the underlying synoptic conditions and physical causes is discussed in Sect. 5.

For winter, the influence of the MO pattern is the most geographically wide-spread, with the MOI-1 index exhibiting stronger relationships than the MOI-2 index (Table 7). The NAO/AO patterns, which are partly correlated with the MO (e.g., Dünkeloh and Jacobeit, 2003, Table 4), exhibit their strongest impact in south-eastern case-study domains. Across the Mediterranean, the SLP-based NAO-CRU index is selected somewhat more frequently than the $500-\mathrm{mb}$ geopotential height-based NAO-CPC index (Table 9). For the other mid-tropospheric indices, the EA/WR pattern affects cold extremes in Eastern Mediterranean domains, and less strongly warm extremes in Western Mediterranean domains. Some indications are also found of EA pattern influence in the Central Mediterranean (Italy). The SCAND pattern is related weakly with cold extremes in the southwest Mediterranean (Oran). As expected (Kutiel et al., 2002), the NCP appears as probably the most influential pattern for the Eastern Mediterranean region and has preferably high skill in explaining cold extremes there. Previous studies focused on the impact of the EMP in the Eastern Mediterranean (Hatzaki et al., 2009). Here it is found that the influence of the EMP is considerably more extensive and is actually stronger in the Central and Western than in the Eastern Mediterranean (see also discussion of Fig. 8 in Sect. 5). Cold extremes are most strongly affected by the EMP in the Gulf of Gabès and warm extremes in Valencia. All case-study domains appear to be affected by the major Euro-Atlantic atmospheric circulation patterns to a considerable degree. Nevertheless, the diversity of this influence among the various domains and also the indices of extremes show a geographical and/or climatic preference. In particular, cold extremes (especially TN5n) in the Southern Mediterranean domains (i.e., Gulf of Oran, Gulf of Gabès, Alexandria, Judean Foothills, and Beirut) exhibit the closest relationship with the atmospheric patterns (also confirmed by a preliminary multiple regression analysis - not shown here - using the circulation indices appearing in Table 7). With regard to duration-related indices of extremes, the duration of cold events (CWDI) appears more prone to the influence of large-scale patterns than the duration of warm events (WSDI and HWDI).

For summer, the SNAO dominates in north-central and north-eastern case-study domains (most markedly in Apulia), and particularly with respect to hot extremes (Table 9). The NAO pattern (CRU and CPC variants) exhibits moderatestrength links with extremes over the Central and Eastern Mediterranean, but extends its influence over southern casestudy domains too (mainly over Alexandria and more weakly in the Gulf of Gabès and Gulf of Oran). The SLP-based NAO-CRU index appears more important for cold extremes, and the mid-tropospheric NAO-CPC index more important for hot extremes (Table 9). The EA/WR pattern also affects the Eastern Mediterranean, but exhibits modest correlations and preferentially affects cold extremes. Summer extremes over Western Mediterranean case-study domains (i.e., Gulf of Valencia and Gulf of Oran) are the least influenced by the large-scale atmospheric circulation patterns considered here.

Time-series plots of observed indices of extremes and reconstructed values from the linear regressions are shown in Figs. 6 and 7 for winter and summer, respectively, for selected case-study domains and for some of the most influential circulation indices (EA/WR, NCP, MOI-1, and EMP for winter and EA/WR and SNAO for summer). The variance explained is shown above each time series and reaches maximum values in winter of $54 \%$ and $53 \%$ with NCP for Alexandria and the Judean Foothills, respectively. As previously noted, values are generally lower in summer.

In winter (Fig. 6), the regression relationships are able to account, at least partially, for some of the observed peaks, but generally these are underestimated (Fig. 6). It is also evident in a number of cases (most notably for TX95n for Beirut and the Judean Foothills - Fig. 6c), that the reconstructed values diverge from the observed values over the last $10 \mathrm{yr}$ and fail to capture the observed upward trend in warm extremes over this period. In the case of TN5n for Athens, the reconstructed values fail to capture the observed recent increase in cold extremes. In the case of summer (Fig. 7), observed and reconstructed values diverge over the last $15-20 \mathrm{yr}$ and the divergence is more marked than in winter. In all cases, the reconstructions fail to reproduce the observed decrease in cold extremes (Fig. 7a), and severely underestimate the observed large increases in hot extremes over the last $20 \mathrm{yr}$ or so (Fig. 7b). This indicates that circulation changes are not the main cause of the enhanced warming or the change point at the end of the 1970s evident in some extremes (Sect. 3). Other potential causes are discussed at the end of Sect. 5.

\section{Summary, discussion and conclusions}

The analysis of two complementary gridded datasets (Sect. 2), one based on station data (E-OBS) and the other on reanalysis (ERA-40/interim), indicates how temperature extremes in the Mediterranean, as measured by a number of different indices, have varied over the last $50 \mathrm{yr}$. While the observed trends are generally consistent in both datasets and with the global trends of temperature and their extremes, i.e., more warm/hot extremes and fewer cold extremes, the regional analysis reveals a more complex picture of spatial and temporal variability (Sect. 3).

Trends of indices of temperature extremes in the Mediterranean appear to have a more diverse character in winter and, in contrast, to be quite uniform in summer. In winter, cold extremes are decreasing over the Mediterranean (in most places, albeit with no strongly significant trends) except in its north-eastern part where a near-steady increase is found. Warm extremes increase in winter (in the case 
HWDI trends (1989-2008)
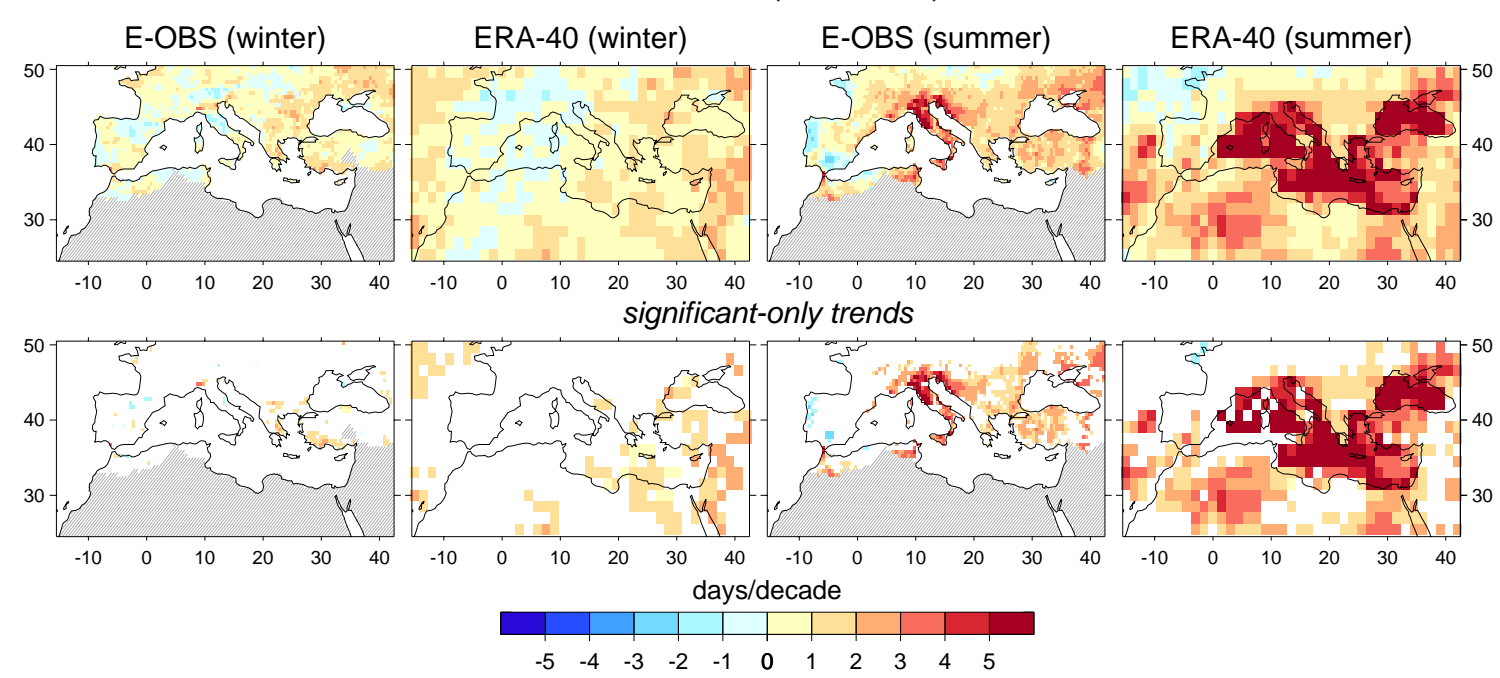

Fig. 5. Trends of winter (left-hand columns) and summer (right-hand columns) HWDI (days per decade), over the period 1989-2008, from E-OBS and ERA-40 data. The lower panel shows only statistically-significant trends.

of TX95n, for example, these trends are statistically significant over most of the region), while a contrasting decrease takes place in the eastern Mediterranean. In summer, the increase of warm/hot extremes is most pronounced in the Central and Eastern Mediterranean (but is statistically significant over most of the Mediterranean in the case of TX95n). The warming trends in summer (prominent in warm/hot indices of extremes, i.e., TN95n, TX95n, WSDI, and HWDI) seem to have intensified over the most recent two decades (19892008).

Linear regression and correlation analysis has been used to explore potential relationships between the indices of extremes and well-documented large-scale atmospheric circulation patterns in the Euro-Atlantic domain: the NAO, AO, and MOI together with the more regional SCAND, EA, EA/WR, NCP, and EMP patterns (Sect. 4). The focus of this analysis is 10 case-study domains scattered across the Mediterranean. Several noticeable relationships are found and the influential circulation patterns vary both across the region and from season to season, with relationships generally stronger in winter than in summer. For winter, the MOI seems to have the most widespread geographic influence, with the NAO/AO having a similar influence to the MOI across the basin, and the NCP and EA/WR affecting mainly the Eastern Mediterranean. While previous studies have indicated the influence of the EMP pattern in the Eastern Mediterranean, here its influence is shown to be considerably more widespread across the Mediterranean (see discussion of Fig. 8 later in this section). For summer, the SNAO is influential in north-central and north-eastern case-study domains.
Extremes/circulation relationships have been identified using both un-filtered and filtered time series: the latter allows focus on high-frequency (interannual) variability. In general, however, the regression and correlation relationships for single circulation indices are rather weak and cannot fully account for observed peaks or trends. The SNAO regression relationships for summer, for example, underestimate the marked increase in hot/warm extremes observed in the Central/Eastern Mediterranean in the last 10-20 yr (Fig. 7b).

The aim of this study was to identify specific circulation indices which may have some influence on the occurrence of extremes and how these influences vary with season and location. Having identified these circulation patterns using rather simple linear methods, more sophisticated statistical approaches can be used to build more appropriate models for applications such as explaining the causes of the observed trends in extremes or statistical downscaling of climate models. For such applications, a number of additional issues need to be considered:

- Use of multiple circulation predictors (taking due account of correlated circulation indices, Table 4)

- Linearity of relationships - are non-linear techniques such as neural networks more appropriate than linear regression?

- Stability and stationarity of relationships - at minimum independent calibration/validation periods should be used

Consideration also needs to be given to developing a physical understanding of the statistical relationships identified. Tables 7 and 8 list the most strongly influential relationships 


\section{a) E-OBS TN5n (DJF) vs. EA/WR}

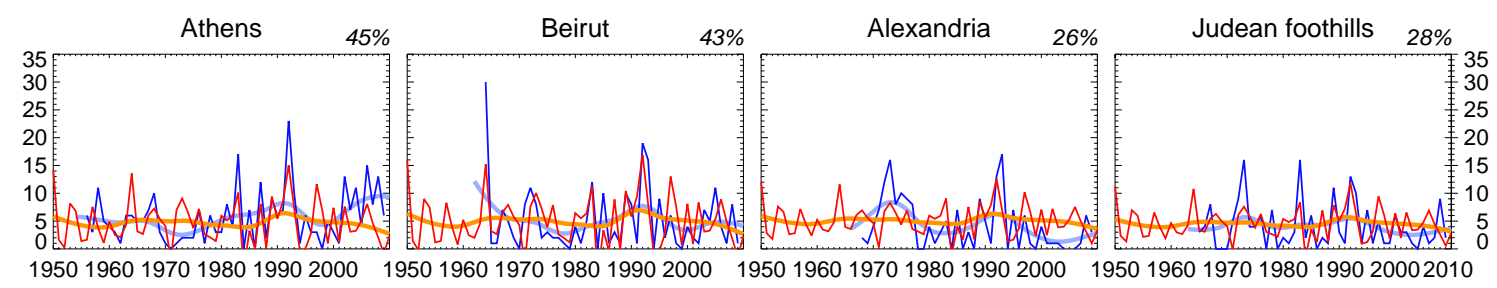

b) E-OBS TX5n (DJF) vs. NCP

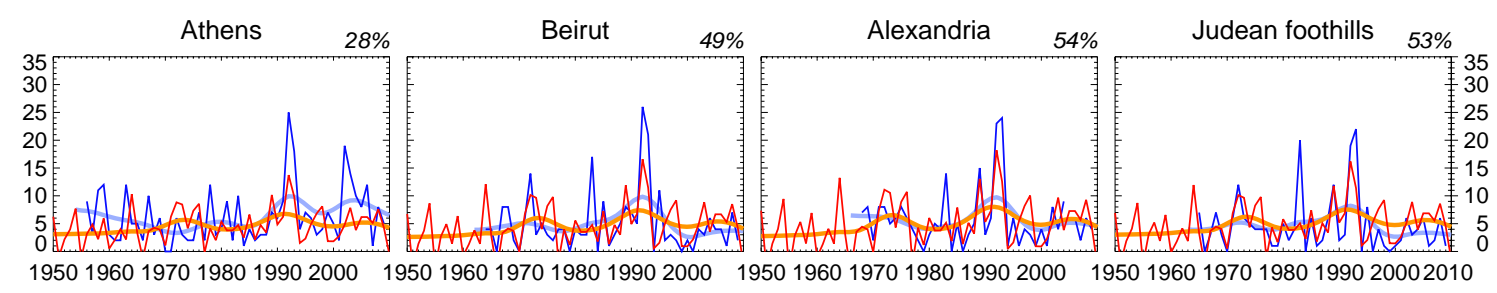

c) E-OBS TX95n (DJF) vs. MOI-1

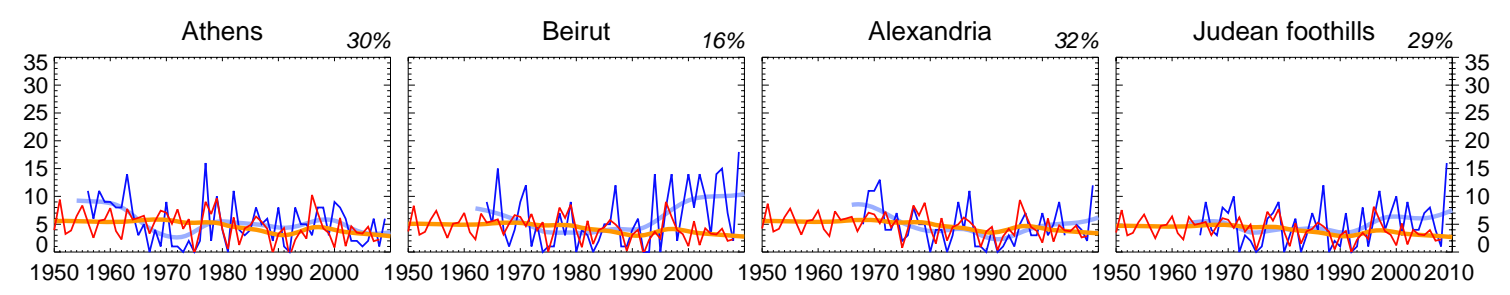

d) E-OBS TG95n (DJF) vs. EMP

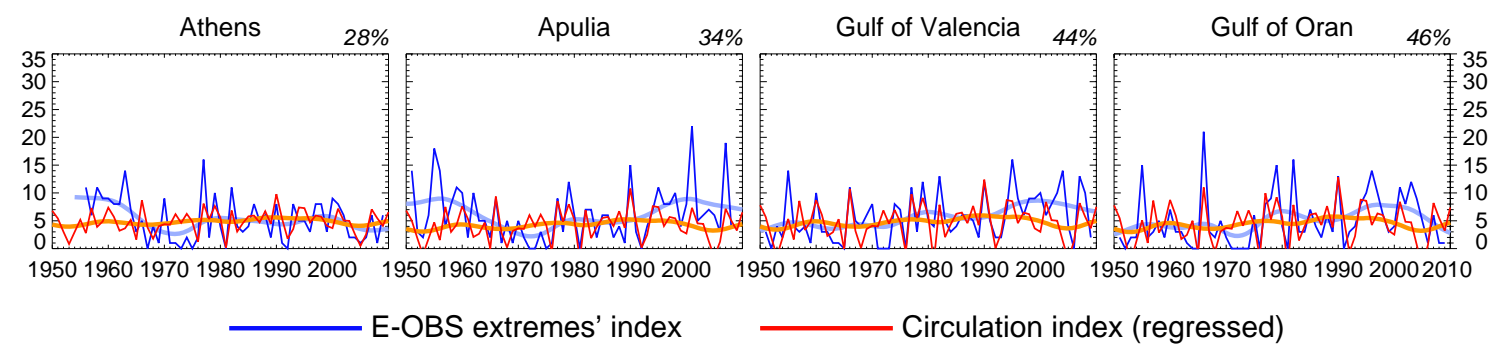

Fig. 6. Winter (DJF) indices of temperature extremes from E-OBS (in blue) for selected case-study domains plotted against reconstructed values (in red) from the atmospheric circulation index linear regressions: (a) TN5n vs. EA/WR, (b) TX5n vs. NCP, (c) TX95n vs. MOI-1, and (d) TG95n vs. EMP. The variance explained (\%) by the circulation index is shown above each plot.

between extremes and circulation indices - while Table 9 indicates the sign of the relationships. Except in the case of SCAND in winter and summer and a couple of single-station exceptions in summer, relationships are consistently positive for cold extremes and negative for warm/hot extremes (reflecting the sign of the correlations between the circulation indices - Table 4). For the NAO and AO indices, the relationships with winter extremes are consistent with previous studies of both mean (Hurrell and van Loon, 1997) and extreme (Scaife et al., 2008; Kenyon and Hegerl, 2008) temperature (see Sect. 2), i.e., cold extremes in the Mediterranean are associated with positive phases of the NAO.
Figure 8 shows both the sign and strength of the relationships for a number of selected examples for the whole Mediterranean rather than just the case-study domains. In winter, TN5n over Turkey is positively correlated with the EA/WR, MOI-1, and even more strongly with NCP, while TG95n over Turkey is negatively correlated with MOI-1 and NCP (Fig. 8a). In the western Mediterranean, TN5n is positively correlated with both MOI-1 (only over North Africa) and EMP, while TG95n is negatively correlated with EMP (particularly over the Iberian Peninsula). EA/WR and NCP are associated with anomalously northerly wind flow in the eastern Mediterranean (Krichak et al., 2002; Kutiel 
a) E-OBS TN5n (JJA) vs. EA/WR

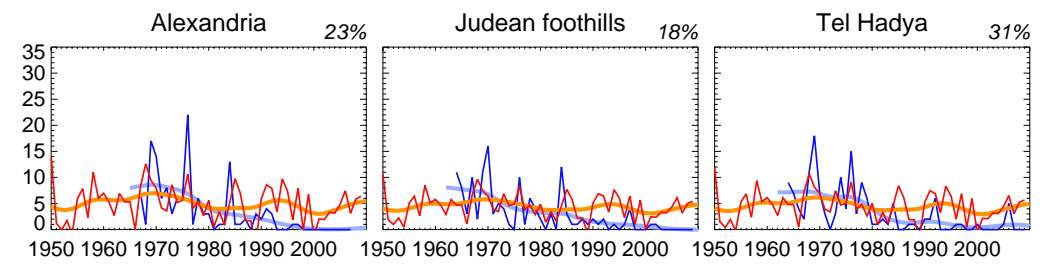

b) E-OBS TX95n (JJA) vs. SNAO

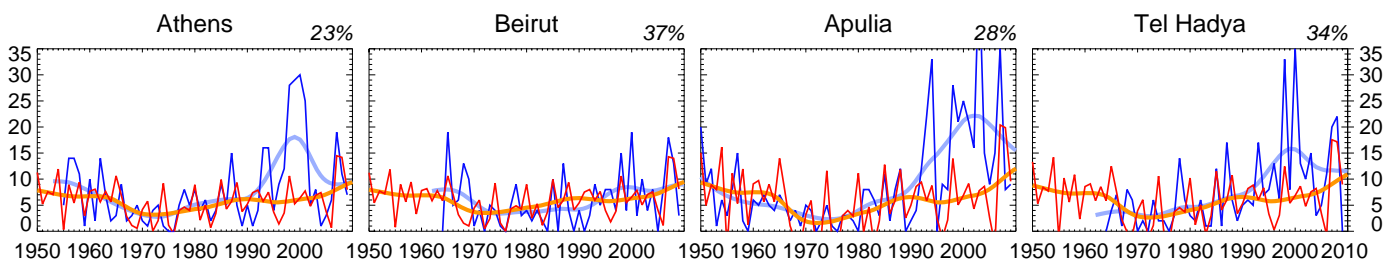

E-OBS extremes' index

Circulation index (regressed)

Fig. 7. Observed (blue) indices of temperature extremes against reconstructed values (red), as in Fig. 6, but for summer (JJA): (a) TN5n vs. EA/WR, (b) TX95n vs. SNAO.

a) E-OBS extremes (DJF) vs. circulation indices
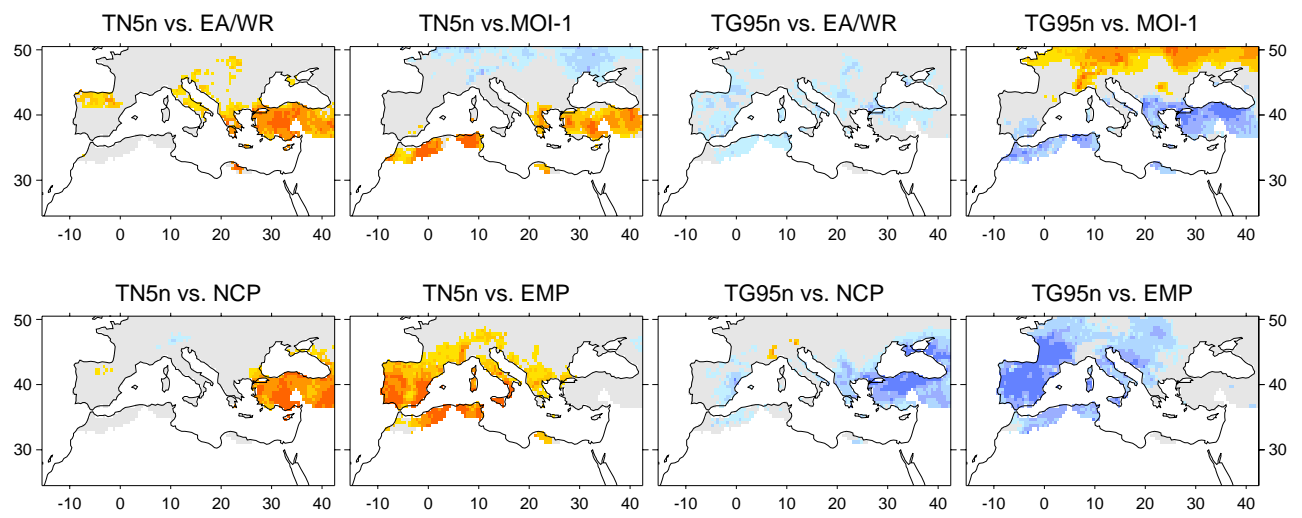

b) E-OBS extremes (JJA) vs. circulation indices

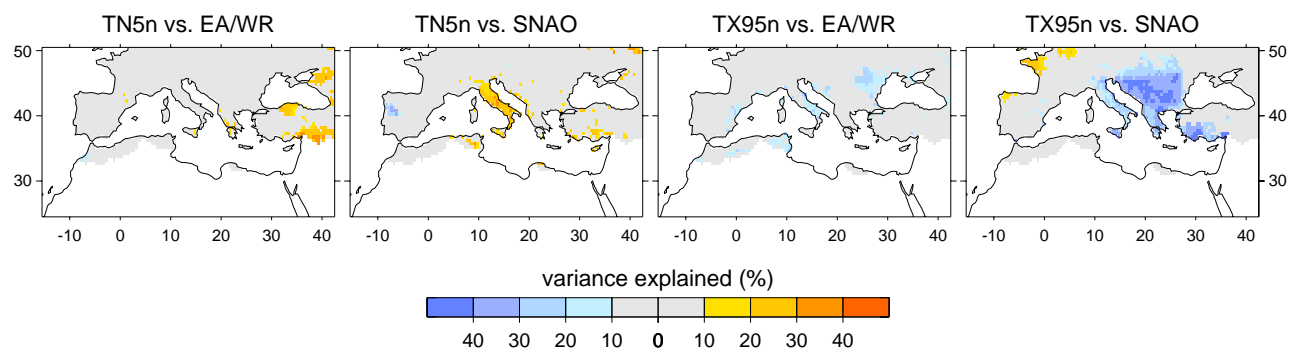

Fig. 8. Skill of the most important circulation indices for winter (upper two rows) and summer (bottom row) in explaining the variance (expressed in \%) of indices of temperature extremes (unfiltered time series) calculated from E-OBS (TN5n, TG95n, and TX95n) for 1958-2008. Red/blue shades indicate positive/negative relationships between circulation and indices of extremes (shown only for variance explained $>10 \%$ ). 
and Benaroch, 2002), which is consistent with the positive TN5n and negative TG95n correlations. The positive phase of the EMP is associated with a positive $500 \mathrm{hPa}$ geopotential height anomaly centred to the west of the British Isles and a less extensive anomaly centred over the western part of the Black Sea (Hatzaki et al., 2007). This brings anomalous northerly flow down the North Sea, through France, and over the Western Mediterranean; and anomalous northwesterly flow over the Balkan Peninsula and into the Eastern Mediterranean. This is consistent with the positive relationships between EMP and cold extremes identified here.

In summer, TX95n is negatively correlated with SNAO over large parts of the eastern Mediterranean, while TN5n is positively correlated with this pattern over Italy (Fig. 8b). SNAO is associated with a characteristic large-scale pressure pattern centred over the North Sea and British Isles, which affects wind flow and cloudiness in the Eastern Mediterranean. In the SNAO positive phase (with anticyclonic conditions in NW Europe), anomalous northeasterly winds and increased cloudiness favour lower-than-normal temperatures in the Eastern Mediterranean and vice versa for the negative phase of SNAO (Xoplaki et al., 2003a, b; Kostopoulou and Jones, 2007a, b; Folland et al., 2009). This could account, in part, for the observed positive correlation with cold extremes and negative correlation with hot extremes (Fig. 8). Further exploration of the synoptic processes underlying the statistical relationships identified here would help to increase confidence in any statistical model based on these relationships.

Physical process understanding is also important for the identification of factors which may be missing from the analysis. The literature review conducted for this study, for example, identified blocking conditions as a mechanism associated with warm/hot temperatures in the Western Mediterranean (Sect. 2). Thus, the analysis could be repeated using one or more of the available Atlantic blocking indices (Tibaldi and Molteni, 1990; Scherrer et al., 2006). Moreover, the frequency and persistence of mesoscale patterns may also play a considerable role in the year-to-year variations of indices of extremes as well as their trends (Domonkos et al., 2003; Kyselý, 2008).

While the study presented here confirms a number of the relationships between Mediterranean temperature extremes and large-scale circulation previously identified or proposed (see Sect. 2), it also indicates the complexity of these relationships - in terms of both their temporal and spatial variability. Furthermore, it indicates that it is unlikely that atmospheric circulation variability alone can explain the observed trends in extremes and, in particular, the amplification of the trends in warm/hot extremes in the last decade. The influence of other factors such as warming sea surface temperatures (Xoplaki et al., 2003a, b; Zveryaev and Arkhipkin, 2008a, b) also needs to be considered in future studies, together with feedback mechanisms such as soil moisture feedbacks in summer (Seneviratne et al., 2006, 2010). A relationship has recently been found between soil-moisture deficit - as expressed by the standardised precipitation index - and summer hot extremes in southeastern Europe (Hirschi et al., 2010). The distribution of both series show a significant shift in location at 1980/1981, and the authors conclude that "part of the observed trend in the hot extremes could have resulted from trends in moisture availability". However, it is also possible that the enhanced warming in both summer and winter is, in part, a reflection of trends in global dimming and brightening (Wild, 2009). Whatever their causes, these recent trends demonstrate the importance of continuing to monitor temperature extremes through a high-quality observed data network.

Acknowledgements. This research was funded by the 6th EU Framework Programme CIRCE (Climate Change and Impact Research: the Mediterranean Environment; http://www.circeproject.eu/; contract number 036961).

Edited by: P. Lionello

Reviewed by: two anonymous referees

\section{References}

Alexander, L. V., Zhang, X., Peterson, T. C., Caesar, J., Gleason, B., Klein Tank, A. M. G., Haylock, M., Collins, D., Trewin, B., Rahimzadeh, F., Tagipour, A., Rupa Kumar, K., Revadekar, J., Griffiths, G., Vincent, L., Stephenson, D.B., Burn, J., Aguilar, E., Brunet, M., Taylor, M., New, M., Zhai, P., Rusticucci, M., and Vazquez-Aguirre, J. L.: Global observed changes in daily climate extremes of temperature and precipitation, J. Geophys. Res., 111, D05109, doi:10.1029/2005JD006290, 2006.

Baldi, M., Dalu, G., Maracchi G., Pasqui, M., and Cesarone, F.: Heat waves in the Mediterranean: a local feature or a larger-scale effect?, Int. J. Climatol., 26(11), 1477-1487, doi:10.1002/joc.1389, 2006.

Bartolini, G., Morabito, M., Crisci, A., Grifoni, D., Torrigiani, T., Petralli, M., Maracchi, G., and Orlandini, S.: Recent trends in Tuscany (Italy) summer temperature and indices of extremes, Int. J. Climatol., 28(13), 1751-1760, doi:10.1002/joc.1673, 2008.

Brunet, M., Jones, P. D., Sigró, J., Saladié, O., Aguilar, E., Moberg, A., Della-Marta, P. M., Lister, D., Walther, A., and López, D.: Temporal and spatial temperature variability and change over Spain during 1850-2005, J. Geophys. Res., 112, D12117, doi:10.1029/2006JD008249, 2007.

Carril, A., Gualdi, F. S., Cherchi, A., and Navarra, A.: Heatwaves in Europe: areas of homogeneous variability and links with the regional to large-scale atmospheric and SSTs anomalies, Clim. Dynam., 30(1), 77-98, doi:10.1007/s00382-007-0274-5, 2007.

Conte, M., Giuffrida, A. and Tedesco, S.: The Mediterranean Oscillation: Impact on precipitation and hydrology in Italy, In: Conference on Climate and Water, 1, 121-137, Publications of the Academy of Finland, 9/89, Helsinki, Finland, 1989.

Domonkos, P., Kyselý, J., Piotrowicz, K., Petrovic, P., and Likso, T.: Variability of extreme temperature events in southcentral Europe during the 20th century and its relationship with large scale circulation, Int. J. Climatol., 23(9), 987-1010, doi:10.1002/joc.929, 2003. 
Domroes, M. and El-Tantawi, A.: Recent temporal and spatial temperature changes in Egypt, Int. J. Climatol., 25(1), 51-63, doi:10.1002/joc.1114, 2005.

Dünkeloh, A. and Jacobeit., J.: Circulation dynamics of Mediterranean precipitation variability 1948-98, Int. J. Climatol., 23, 1843-1866, doi:10.1002/joc.973, 2003.

El Kenawy, A. M., López-Moreno, J. I., Vicente-Serrano, S. M., and Mekld, M. S.: Temperature trends in Libya over the second half of the 20th century, Theor. Appl. Climatol., 98(1-2), 1-8, doi: 10.1007/s00704-008-0089-2, 2009.

Folland, C. K., Knight, J., Linderholm, H. W., Fereday, D., Ineson, S., and Hurrell, J. W.: The Summer North Atlantic Oscillation: Past, present, and future, J. Climate, 22(5), 1082-1103, doi:10.1175/2008JCLI2459.1, 2009.

Founda, D., Papadopoulos, K. H., Petrakis, M., Giannakopoulos, C., and Good, P.: Analysis of mean, maximum, and minimum temperature in Athens from 1897 to 2001 with emphasis on the last decade: trends, warm events, and cold events, Global Planet. Change, 44(1-4), 27-38, doi:10.1016/j.gloplacha.2004.06.003, 2004.

Founda, D. and van Loon, H.: Circulation anomalies associated with winter temperature extremes in Athens during the period 1900-2004, Meteorol. Z., 17(1), 55-59, doi:10.1127/09412948/2007/0260, 2008.

Frich, P., Alexander, L. V., Della-Marta, P., Gleason, B., Haylock, M., Klein-Tank, A. M. G., and Peterson, T.: Observed coherent changes in climatic extremes during second half of the twentieth century, Clim. Res., 19(3), 193-212, doi:10.3354/cr019193, 2002

Hatzaki, M., Flocas, H. A., Asimakopoulos, D. N., and Maheras, P.: The Eastern Mediterranean teleconnection pattern: Identification and definition, Int. J. Climatol., 27(6), 727-737, doi:10.1002/joc.1429, 2007.

Hatzaki, M., Flocas, H. A., Giannakopoulos, C., and Maheras, P.: The impact of the Eastern Mediterranean teleconnection pattern on the Mediterranean climate, J. Climate, 22(4), 977-992, doi:10.1175/2008JCLI2519.1, 2009

Haylock, M. R., Hofstra, N., Klein Tank, A. M. G., Klok, E. J., Jones, P. D., and New, M.: A European daily highresolution gridded data set of surface temperature and precipitation for 1950-2006, J. Geophys. Res., 113, D20119, doi:10.1029/2008JD010201, 2008.

Hirschi, M., Seneviratne, S. I., Alexandrov, V., Boberg, F., Boroneant, C., Christensen, O. B., Formayer, H., Orlowsky, B., and Stepanek, P.:, Observational evidence for soil-moisture impact on hot extremes in southeastern Europe, Nature Geosci., 4(1), (17-21), doi:10.1038/NGEO1032, 2010.

Hurrell, J. W. and van Loon, H.:, Decadal variations in climate associated with the North Atlantic Oscillation, Climatic Change, 36(3-4), 301-326, doi:10.1023/A:1005314315270, 1997.

Intergovernmental Panel on Climate Change (IPCC): Climate Change 2007: The Physical Basis, Contribution of Working Group I to the Fourth Assessment Report of the Intergovernmental Panel on Climate Change, edited by: Solomon, S., Qin, D., Manning, M., Chen, Z., Marquis, M., Averyt, K. B., Tignor, M., and Miller, H. L., Cambridge Univ. Press, Cambridge, UK and New York, NY, USA, 2007.

Kalnay, E., Kanamitsu, M., Kistler, R., Collins, W., Deaven, D.,
Gandin, L., Iredell, M., Saha, S., White, G., Woollen, J., Zhu, Y., Leetmaa, A., Reynolds, R., Chelliah, M., Ebisuzaki, W., Higgins, W., Janowiak, J., Mo, K. C., Ropelewski, C., Wang, J., Jenne, R., and Joseph, D.: The NCEP/NCAR 40-year reanalysis project, B. Am. Meteorol. Soc., 77(3), 437-471, doi:10.1175/15200477(1996)077<0437:TNYRP>2.0.CO;2, 1996.

Kenyon, J. and Hegerl, G. C.: Influence of modes of climate variability on global temperature extremes, J. Climate, 21(15), 38723889, doi:10.1175/2008JCLI2125.1, 2008.

Kistler, R., Kalnay, E., Collins, W., Saha, S., White, G., Woollen, J., Chelliah, M., Ebisuzaki, W., Kanamitsu, M., Kousky, V., van den Dool. H., Jenne, R., and Fiorino, M.: The NCEP-NCAR 50-year reanalysis: Monthly means CD-ROM and documentation, B. Am. Meteorol. Soc., 82(2), 247-267, doi:10.1175/15200477(2001)082<0247:TNNYRM>2.3.CO;2, 2001.

Klein Tank, A. M. G., and Können, G. P.: Trends in indices of daily temperature and precipitation extremes in Europe, 1946-99, J. Climate, 16(22), 3665-3680, doi:10.1175/15200442(2003)016<3665:TIIODT>2.0.CO;2, 2003.

Kostopoulou, E. and Jones, P. D.: Assessment of climate extremes in the Eastern Mediterranean, Meteorol. Atmos. Phys., 89(1-4), 69-85, doi:10.1007/s00703-005-0122-2, 2005.

Kostopoulou, E. and Jones, P. D.: Comprehensive analysis of the climate variability in the eastern Mediterranean. Part I: map-pattern classification, Int. J. Climatol., 27(9), 1189-1214, doi:10.1002/joc.1467, 2007a.

Kostopoulou, E. and Jones, P. D.: Comprehensive analysis of the climate variability in the eastern Mediterranean. Part II: relationships between atmospheric circulation patterns and surface climatic elements, Int. J. Climatol., 27(10), 1351-1371, doi:10.1002/joc.1466, 2007b.

Krichak, S. O., Kishcha, P., and Alpert, P.: Decadal trends of main Eurasian oscillations and the Eastern Mediterranean precipitation, Theor. Appl. Climatol., 72(3-4), 209-220, doi:10.1007/s007040200021, 2002.

Kuglitsch, F. G., Toreti, A., Xoplaki, E., Della-Marta, P. M., Zerefos, C., Türkeş, M., and Luterbacher, J.: Heat wave changes in the eastern Mediterranean since 1960, Geophys. Res. Lett., 37, L0482, doi:10.1029/2009GL041841, 2010.

Kutiel, H. and Benaroch, Y.: North Sea-Caspian Pattern (NCP) an upper level atmospheric teleconnection affecting the Eastern Mediterranean: Identification and definition, Theor. Appl. Climatol., 71(1-2), 17-28, doi:10.1007/s704-002-8205-x, 2002.

Kutiel, H., Maheras, P., Türkeş, M., and Paz, S.:, North Sea Caspian Pattern (NCP) - an upper level atmospheric teleconnection affecting the eastern Mediterranean - implications on the regional climate, Theor. Appl. Climatol., 72(3-4), 173-192, doi:10.1007/s00704-002-0674-8, 2002.

Kyselý, J.: Influence of the persistence of circulation patterns on warm and cold temperature anomalies in Europe: Analysis over the 20th century, Global Planet. Change, 62(1-2), 147-163, doi:10.1016/j.gloplacha.2008.01.003, 2008.

Moberg, A. and Jones, P. D.: Trends in indices for extremes in daily temperature and precipitation in central and western Europe, 1901-99, Int. J. Climatol., 25(9), 1149-1171, doi:10.1002/joc.1163, 2005

Moberg, A., Jones, P. D., Lister, D., Walther, A., Brunet, M., Jacobeit, J., Alexander, L. V., Della-Marta, P. M., Luterbacher, J., Yiou, P., Chen, C., Klein Tank, A. M. G., Saladié, O., 
Sigró, J., Aguilar, E., Alexandersson, H., Almarza, C., Auer, I., Barriendos, M., Begert, M., Bergström, H., Böhm, R., Butler, C. J., Caesar, J., Drebs, A., Founda, D., Gerstengarbe, F.W., Micela, G., Maugeri, M., Österle, H., Pandzic, K., Petrakis, M., Srnec, L., Tolasz, R., Tuomenvirta, H., Werner, P. C., Linderholm, H., Philipp, A., Wanner, H., and Xoplaki, E.: Indices for daily temperature and precipitation extremes in Europe analyzed for the period 1901-2000, J. Geophys. Res., 111, D22106, doi:10.1029/2006JD007103, 2006.

Palutikof, J. P, Conte, M., Casimiro Mendes, J., Goodess, C. M., and Esprito Santo, F.: Climate and climatic change, in: Mediterranean Desertification and Land Use, edited by: Brandt, C. J. and Thornes, J. B., Wiley, New York, 43-86, 1996.

Rodríguez-Puebla, C., Encinas, A. H., García-Casado, L. A., and Nieto, S.: Trends in warm days and cold nights over the Iberian Peninsula: relationships to large-scale variables, Climatic Change, 100(3-4), 667-684, doi:10.1007/s10584-009-9721-0, 2010.

Scaife, A., Folland, C. K., Alexander, L. V., Moberg, A., and Knight, J. R.: European climate extremes and the North Atlantic Oscillation, J. Climate, 21(1), 72-83, doi:10.1175/2007JCLI1631.1, 2008.

Scherrer, S., Croci-Maspoli, M., Schwierz, C., and Appenzeller, C.: Two-dimensional indices of atmospheric blocking and their statistical relationship with winter climate patterns in the Euro-Atlantic region, Int. J. Climatol., 26(2), 233-249, doi:10.1002/joc.1250, 2006.

Seneviratne, S.I., Lüthi, D., Litschi, M., and Schär, C.: Landatmosphere coupling and climate change in Europe, Nature, 443(7108), 205-209, doi:10.1038/nature05095, 2006.

Seneviratne, S. I., Corti, T., Davin, E. L., Hirschi, M., Jaeger, E. B., Lehner, I., Orlowsky, B., and Teuling, A. J.: Investigating soil moisture-climate interactions in a changing climate: A review, Earth-Sci. Rev., 99(3-4), 125-161, doi:10.1016/j.earscirev.2010.02.004, 2010.

Sensoy, S., Peterson, T. C., Alexander, L. V., and Zhang, X.: Middle East climate change monitoring and indexes, B. Am. Meteorol. Soc., 88(8), 1249-1254, doi:10.1175/BAMS-88-8-1249, 2007.

Simmons, A., Uppala, S., Dee, D., and Kobayashi, S.: ERAInterim: New ECMWF reanalysis products from 1989 onwards, ECMWF Newsletter, 110, 25-35, European Centre for MediumRange Weather Forecasts, Shinfield Park, Reading, Berkshire RG2 9AX, UK, 2006.

Tibaldi, S. and Molteni, F.: On the operational predictability of blocking, Tellus A, 42(3), 343-365, doi:10.1034/j.16000870.1990.t01-2-00003.x, 1990.

Tolika, K., Maheras, P., and Tegoulias, I.: Extreme temperatures in Greece during 2007: Could this be a "return to the future"? Geophys. Res. Lett., 36, L10813, doi:10.1029/2009GL038538, 2009.
Toreti, A. and Desiato, F.: Changes in temperature extremes over Italy in the last 44 years, Int. J. Climatol., 28(6), 733-745, doi:10.1002/joc.1576, 2008.

Uppala, S. M., Kållberg, P. W., Simmons, A. J. , Andrae, U., da Costa Bechtold, V., Fiorino, M., Gibson, J. K., Haseler, J., Hernandez, A., Kelly, G. A., Li, X., Onogi, K., Saarinen, S., Sokka, N., Allan, R. P., Andersson, E., Arpe, K., Balmaseda, M. A., Beljaars, A. C. M., van de Berg, L., Bidlot, J., Bormann, N., Caires, S., Chevallier, F., Dethof, A., Dragosavac, M., Fisher, M., Fuentes, M., Hagemann, S., Hólm, E., Hoskins, B. J., Isaksen, L., Janssen, P. A. E. M., Jenne, R., McNally, A. P., Mahfouf, J.-F., Morcrette, J.-J., Rayner, N. A., Saunders, R. W., Simon, P., Sterl, A., Trenberth, K. E., Untch, A., Vasiljevic, D., Viterbo, P., and Woollen, J.: The ERA-40 Reanalysis, Q. J. Roy. Meteor. Soc., 131, 2961-3012, doi:10.1256/qj.04.176, 2005.

Wild, M.:, Global dimming and brightening: A review, J. Geophys. Res., 114, D00D16, doi:10.1029/2008JD011470, 2009.

Xoplaki, E., González-Rouco, J. F., Gyalistras, D., Luterbacher, J., Rickli, R., and Wanner, H.: Interannual summer air temperature variability over Greece and its connection to the large-scale atmospheric circulation and Mediterranean SSTs 1950-1999, Clim. Dynam., 20(5), doi:10.1007/s00382-002-0291-3, 2003a.

Xoplaki, E., González-Rouco, J. F., Luterbacher, J., and Wanner, H.: Mediterranean summer air temperature variability and its connection to the large-scale atmospheric circulation and SSTs, Clim. Dynam., 20(7-8), 723-739, doi:10.1007/s00382003-0304-x, 2003b.

Yan, Z., Jones, P. D., Davies, T. D., Moberg, A., Bergström, H., Camuffo, D., Cocheo, C., Maugeri, M., Demarée, G. R., Verhoeve, T., Thoen, E., Barriendos, M., Rodríguez, R., Martín-Vide, J., and Yang, C.: Trends of extreme temperatures in Europe and China based on daily observations, Climatic Change, 53(1), 355392, doi:10.1023/A:1014939413284, 2002.

Zhang, X., Aguilar, E., Sensoy, S., Melkonyan, H., Tagiyeva, U., Ahmed, N., Kutaladze, N., Rahimzadeh, F., Taghipour, F., Hantosh, T. H., Albert, P., Semawi, M., Ali, M. K., Al-Shabibi, M. H. S., Al-Oulan, Z., Zatari, T., Khelet, I. A. D., Hamoud, S., Sagir, R., Demircan, M., Eken, M., Adiguzel, M., Alexander, L., Peterson, T. C., and Wallis, T.: Trends in Middle East climate extreme indices from 1950 to 2003, J. Geophys. Res., 110, D22104, doi:10.1029/2005JD006181, 2005.

Zveryaev, I. I. and Arkhipkin, A. V.: Structure of climatic variability of the Mediterranean sea surface temperature, Part I. Standard deviations and linear trends, Russ. Meteorol. Hydrol., 33(6), 377-382, doi:10.3103/S1068373908060058, 2008a.

Zveryaev, I. I. and Arkhipkin, A. V.: Structure of climatic variability of the Mediterranean sea surface temperature, Part II. Principal modes of variability, Russ. Meteorol. Hydrol., 33(7), 446-452, doi:10.3103/S1068373908070066, 2008b. 